\title{
REDEVISED EDITION OF PHYSICAL SKILLS COMPETENCIES OF PHYSICAL EDUCATION CURRICULUM CONTENT OF THE THIRD YEAR SECONDARY SCHOOL IN OMAN
}

\author{
Yousra Al-Sinani ${ }^{i}$ \\ Associate Professor, \\ Curriculum and Instructions Physical Education, \\ College of Education, Sultan Qaboos University,
}

Oman

\begin{abstract}
:
The present study was designed to continue exploration to ensure the availability of physical skills; By examining the physical education curriculum to investigating the relationship between the goals of the physical education curriculum content and physical skills of the third year secondary school in Oman. The present study sought to examine the physical skills divided in the physical education lesson. The physical education context has been reconstructed at secondary school in Oman. In addition, the present study sought to analyze the Physical Education curriculum document for the third years with the degree of distribution of physical skills and cognitive competencies. Furthermore, the present study sought to suggest the distribution of the same skill competencies among a 10 lesson plan during the third year. The study revealed a weakness in the availability of knowledge competencies according to the Physical skills. The study recommends the strengthening and training of the cognitive skills and competencies.
\end{abstract}

Keywords: physical education; curriculum; physical skills; competencies; third year secondary school

\section{The aim of the study}

The aim of the study is to reflect on physical education curriculum for third year secondary school in Oman. The aim of the study, thus, is to examine the physical skills divided in the physical education lesson and to analyze the Physical Education curriculum document for the third years with the degree of distribution of physical skills and cognitive competencies. The study suggests the distribution of the same physical skill competencies among a 10 lesson plan during the third year. The study revealed a

\footnotetext{
i Correspondence: email yousra@squ.edu.om; alsinaniy@gmail.com
} 
weakness in the availability of knowledge competencies according to the Physical skills, the study will be guided by the following key research question:

1) What are the physical skills divided in the physical education lesson the physical skills were divided in the physical education lesson?

2) What is the distribution of the same physical skill competencies among a 10-lesson plan during the third year?

\section{Significate of the study}

The importance of this research stands in its originality, where it is the first formal attempt to reflect on the Curriculum of third year of physical education at secondary school in Oman. It is, additionally, the first to focus on physical skills distribution in the third year curriculum of PE. This has consequences regarding to issues the physical skills competencies of physical education curriculum, lecturers were asked to rate their level of satisfaction with regard to the activities in schools. The aim of the study, thus, is to fill the signalled gap in the field of physical

\section{Methodology of the research}

In order to provide a general review of availability of physical skills; by examining the physical education curriculum to investigating the relationship between the goals of the physical education curriculum content and physical skills of the third year secondary school in Oman. General reviews will utilize the physical skills divided in the physical education and ability to reconstructed at secondary school in Oman. In addition, the literature was review to analyze the Physical Education curriculum document (Ministry of Education 1991, 1993, 2002a, 2002b, 2005) for the third years with the degree of distribution of physical skills and cognitive competencies and suggest the distribution of the same skill competencies among a 10-lesson plan during the third year. This review is the result of this extensive literature survey.

\section{Introduction}

Physical skills are an important focus of the educational process in learning physical education. As a process it can be realized through nurturing the learner's physical capabilities and developing their essential constituents in the light of the following criteria: understanding the content develops all the components of the learner's overall physical capabilities.

Equality, Balance and Symmetry: balance means giving each component its due diligence in a balanced measure. The process of developing the learner's Hardy \& Mawe (1999) constituents of physical abilities should take into account the physical wellbeing of the learner, his/her acquired and inborn capabilities and age. 
Muscular strength is the ability of muscles to bear extreme external pressures or resistance (Lindeburg, 1978). Muscular durability: muscular durability is the ability of the muscles to exert constant efforts below its maximum potentiality.

Circulatory and respiratory Systems. The ability of the two systems to persevere prolonged bouts of activities (Al Sinani \& Al Rawahi, 2012).

Suppleness, agility, lightness or elasticity of body. The ability to practice different exercises and change body poses commandingly; from a stationary and aerial position.

Flexibility is the ability of the learner to practice different exercises to the best of his/her ability. This obviously requires the flexibility of the joints and elasticity of concerning muscles (Underwood, G. L., 1983). Potentiality It is made up of speed and strength. It is the capability of the learner to exercise maximum effort in minimum space of time (Armstrong, \& Sparkes, 1991; Brown \& Cassidy, 1963). Speed: the capability of the learner to practice repeated exercises in shortest time possible (Phillips \& Hornak, 1999). Harmony, Good Timing, and Synchronisation: the ability of the learner to synchronize different poises or movements of given exercises. Precision: the ability of the learner to control and direct his/her voluntary movements (Al Sinani, 2017).

The ability of the learner to control his/her parts in regard too nervous and muscular systems. Balance - stationary or mobile - should be exercised on a narrow space of ground, in the air, or over aerial gymnastic equipment.

\section{Discussion of the study}

As the development of the physical education curriculum for cycle two and the tired year free, bodybuilding exercises for muscles, which include exercises to cover the body's whole muscular, build protection against muscular injury. The exercises include the neck, head, arms, legs, back, trunk, both sides and belly; balance or body-control exercises. retreat, backward movement exercises; irregular movement exercises; hold-release exercises.

\subsection{Exercises requiring no equipment}

Mobile exercises: walking, running or jogging, jumping, leaping, hopping, and sliding. Stationary exercises: turning around or in circle, mobilizing the upper parts of the body while the legs remaining stationary (Al Sinani, 2012). A selection of free, mobile exercises for sixty-four seconds., exercises involving hand-held objects: rope or streamer. Forward and backward skipping. Turning and swinging rope or streamer in a circular motion. Turning and swinging arms while holding banner (Brown \& Cassidy, 1963). Throwing and receiving the banner. A selection of exercises involving the two objects suggested for sixty-four seconds:
a. Gymnastics for Secondary School - Girls,
b. Carrying out the following activities for a half school year. The duration of exercises is 10 minutes per session,
c. Practicing the Cartwheel, 
d. A selection of exercises which includes forward and backward roll, and handstand,

e. The vaulting horse: vaulting while resting arms on the vaulting horse. Legs remain open in the process.

Note: Alternative exercises should only be used in absence of the equipment of main exercises.

\section{a. Gymnastics for Secondary School - Boys}

Duration of Physical Education Lessons 10 minutes per lesson for half year. Running followed by a stop. Quarter turn for backward roll.

A selection of exercises commencing from a standing stance which includes forward and backward roll in a straight line. Handstand followed by forward roll, then running.

Vaulting horse: flank vault.

Table 1: Gymnastics for Secondary School: Third Year Secondary

\begin{tabular}{|c|c|c|c|c|}
\hline Activity & Description & $\begin{array}{c}\text { Duration of } \\
\text { exercises }\end{array}$ & Gender & Notes \\
\hline Practising the Cartwheel & $\begin{array}{l}\text { A selection of } \\
\text { exercises which } \\
\text { includes forward and } \\
\text { backward roll, and } \\
\text { handstand. }\end{array}$ & $\begin{array}{l}10 \text { Minutes } \\
\text { per session for } \\
\text { a half school } \\
\text { year. }\end{array}$ & Girls & \multirow[t]{2}{*}{$\begin{array}{l}\text { Alternative exercises } \\
\text { should only be used } \\
\text { in absence of the } \\
\text { equipment of main } \\
\text { exercises. }\end{array}$} \\
\hline The vaulting horse & $\begin{array}{l}\text { Vaulting while } \\
\text { resting arms on the } \\
\text { vaulting horse. Legs } \\
\text { remain open in the } \\
\text { process }\end{array}$ & $\begin{array}{l}10 \text { Minutes } \\
\text { per session for } \\
\text { a half school } \\
\text { year. }\end{array}$ & Girls & \\
\hline $\begin{array}{l}\text { Running followed by a } \\
\text { stop. Quarter turn for } \\
\text { backward roll }\end{array}$ & & $\begin{array}{l}10 \text { Minutes } \\
\text { per session for } \\
\text { a half school } \\
\text { year. }\end{array}$ & Boys & \\
\hline $\begin{array}{l}\text { A selection of exercises } \\
\text { commencing from a } \\
\text { standing stance which } \\
\text { includes forward and } \\
\text { backward roll in a } \\
\text { straight line. }\end{array}$ & $\begin{array}{l}\text { Handstand followed } \\
\text { by forward roll, then } \\
\text { running. }\end{array}$ & $\begin{array}{l}10 \text { Minutes } \\
\text { per session for } \\
\text { a half school } \\
\text { year. }\end{array}$ & Boys & \\
\hline Vaulting horse: & Flank vault. & $\begin{array}{l}10 \text { Minutes } \\
\text { per session for } \\
\text { a half school } \\
\text { year. }\end{array}$ & Boys & \\
\hline
\end{tabular}

\section{b. Athletics for Secondary School - Boys \& Girls}

- Running at varying speed for different distances,

- Relay race $4 / 50 \mathrm{~m}-4 / 100 \mathrm{~m}$ depending on the space available, 
- Long Jump (crouching),

- High Jump,

- The Disks $(4 \mathrm{Kg})$ - creeping through a hoop or circle.

Table 2: Third Year Secondary Athletics

\begin{tabular}{|l|c|c|}
\hline Exercises & \multicolumn{2}{|c|}{$\begin{array}{c}\text { Gender } \\
\text { (Boys / Girls) }\end{array}$} \\
\hline Running at varying speed for different distances & $\sqrt{ }$ & $\sqrt{ }$ \\
\hline Relay race 4/50m - 4/100m depending on the space available & $\sqrt{ }$ & $\sqrt{ }$ \\
\hline Long Jump (crouching) & $\sqrt{ }$ & $\sqrt{ }$ \\
\hline High Jump & $\sqrt{ }$ & $\sqrt{ }$ \\
\hline The Disks (4Kg) - creeping through a hoop or circle & $\sqrt{ }$ & $\sqrt{ }$ \\
\hline
\end{tabular}

\section{c. Athletics for Third Year Secondary - Boys}

- Jogging,

- Running,

- Relay,

- Triple Jump,

- Shot ball.

Table 3: Athletics for Third Year Secondary

\begin{tabular}{|l|c|c|}
\hline Exercises & \multicolumn{2}{|c|}{$\begin{array}{c}\text { Gender } \\
\text { Boys / Girls }\end{array}$} \\
\hline Jogging & $\sqrt{ }$ & \\
\hline Running & $\sqrt{ }$ & \\
\hline Relay & $\sqrt{ }$ & \\
\hline Triple Jump & $\sqrt{ }$ & \\
\hline Shot ball & $\sqrt{ }$ & \\
\hline
\end{tabular}

\section{d. Team Games for Secondary School}

- Duration of each session: 10 minutes.

- Team games aim at teaching some individual defensive and attacking skills and team effort for the following games. Rules of games are to be integrated in the teaching of these games:

○ Soccer (boys only),

- Basketball,

- Volleyball,

○ Handball.

Building upon what has been studied in the first and second year, students at this advanced stage are to be taught simplified playing techniques. Rules of the games are to be observed during practices in relation to the level of teaching and practice students have received (Mosston, and Ashworth, (1986) Taba (1962), Massengale (1987)). 
e. Soccer for Third Year Secondary Boys

- Advancing with the football,

- Different types of kicks,

- Balancing and controlling the ball of the thigh,

- Manoeuvrings and eluding,

- Simplified attacking techniques,

- Demonstration and actual soccer practice.

\section{f. Basketball for Third Year Secondary (Boys \& Girls)}

- Passing the ball from different positions (chest pass - one-handed pass),

- Dribbling which is to be taught along with passing and shooting skills as well as the techniques of correct movements,

- Different techniques of shot: two and a one-hand-shot from a stationary position, lay-up, jump shot, jump shot from distance,

- Defensive duties: correct movement and manoeuvrings,

- Demonstration and actual application of the game.

\section{g. Volleyball for Third Year Secondary (Boys \& Girls)}

- Underhand serve,

- The spike or the overhead strikes,

- One/two-player-block,

- Defensive duties,

- Demonstration and actual practice together with teaching simplified rules of the game,

- Skill test.

\section{h. Handball for Third Year Secondary (Boys \& Girls)}

- One-handed-pass: short and long passes,

- Correct reception of ball while charging at the opponents' goal (0/2),

- Rules concerning the area of the defending team,

- Defensive retreat formation $(3 / 3-1 / 5)$,

- Defensive formation $(0 / 6)$,

- Defending against intercepted balls,

- Defending against fast charges,

- Attacking the defensive area,

- Handball contests. 


\begin{tabular}{|c|c|c|c|}
\hline \multicolumn{4}{|c|}{ Table 4: Team Games for Secondary School } \\
\hline Games & Rules & $\begin{array}{l}\text { Duration of } \\
\text { each session }\end{array}$ & Gender \\
\hline Soccer & $\begin{array}{l}\text { - Advancing with the football } \\
\text { - } \text { Different types of kicks } \\
\text { - } \text { Balancing and controlling the ball of the thigh } \\
\text { - } \text { Manoeuvring and eluding } \\
\text { - Simplified attacking techniques } \\
\text { - } \text { Demonstration and actual soccer practice }\end{array}$ & 10 Minutes & $\begin{array}{l}\text { Only } \\
\text { Boys }\end{array}$ \\
\hline Basketball & $\begin{array}{l}\text { - Passing the ball from different positions (chest pass - one- } \\
\text { handed pass) } \\
\text { - Dribbling which is to be taught along with passing and } \\
\text { shooting skills as well as the techniques of correct } \\
\text { movements. } \\
\text { - Different techniques of shot: two and a one-hand-shot } \\
\text { from a stationary position, lay-up, jump shot, jump shot } \\
\text { from distance. } \\
\text { - Defensive duties: correct movement and manoeuvring } \\
\text { - Demonstration and actual application of the game }\end{array}$ & 10 minutes & $\begin{array}{c}\text { Boys } \\
\& \\
\text { Girls }\end{array}$ \\
\hline Volleyball & $\begin{array}{l}\text { - } \text { Underhand Serve } \\
\text { - } \quad \text { The Spike or the overhead strikes } \\
\text { - One/two-player-block } \\
\text { - } \quad \text { Defensive duties } \\
\text { - } \quad \text { Demonstration and actual practice together with teaching } \\
\text { - } \quad \text { Simplified rules of the game }\end{array}$ & 10 Minutes & $\begin{array}{c}\text { Boys } \\
\& \\
\text { Girls }\end{array}$ \\
\hline Handball & $\begin{array}{l}\text { - } \text { One-handed-Pass: short and long passes } \\
\text { - } \text { Correct reception of ball while charging at the opponents' } \\
\text { - }(0 / 2) \\
\text { - } \text { Rules concerning the area of the defending team } \\
\text { - } \text { Defensive retreat formation }(3 / 3-1 / 5) \\
\text { - } \quad \text { Defending against intercepted balls } \\
\text { - } \quad \text { Defending against fast charges } \\
\text { - } \text { Attacking the defensive area } \\
\text { - Handball contests }\end{array}$ & 10 Minutes & $\begin{array}{c}\text { Boys } \\
\& \\
\text { Girls }\end{array}$ \\
\hline
\end{tabular}

\section{Result of the Study}

As literature review for the ministry of education documents the follow are the reshape of the physical skills competencies in the Third Year Secondary (Ministry of Education 1991, 1993, 2002a, 2002b, 2005) - Boys: 


\section{A. Third Year Secondary - Boys}

\subsection{The First Lesson}

Table 5: Third Year Secondary - Boys: 1st Lesson

\begin{tabular}{|c|c|c|}
\hline \multicolumn{3}{|c|}{ Introduction and management } \\
\hline Activity: & - & Description \\
\hline \multirow{6}{*}{ Warm-up } & Jogging for $10 / 20$ Meters. & The exercise is to be repeated several times \\
\hline & Flexibility & $\begin{array}{l}\text { Holding a stick by the hands in a vertical position in } \\
\text { front of thighs }\end{array}$ \\
\hline & $\begin{array}{l}\text { Lifting arms overhead, then } \\
\text { backward towards one's } \\
\text { back. }\end{array}$ & \\
\hline & $\begin{array}{l}\text { Synchronisation and good } \\
\text { timing: }\end{array}$ & Throwing the ball against wall and receiving it \\
\hline & Balancing & $\begin{array}{l}\text { Balancing oneself on the ball using one leg, while } \\
\text { moving the free leg in different directions. Cube, brick or } \\
\text { medical ball can be used instead of the ball. }\end{array}$ \\
\hline & $\begin{array}{l}\text { Strength and Durability of } \\
\text { Muscles: }\end{array}$ & Clasping hands and holding partner. \\
\hline \multicolumn{3}{|c|}{ Exercises required } \\
\hline \multicolumn{3}{|c|}{ Gymnastics: vaulting Horse } \\
\hline \multirow{2}{*}{$\begin{array}{l}\text { Team } \\
\text { games: } \\
\text { Basketball }\end{array}$} & Passes & Chest-pass, one-handed pass and intercepted pass \\
\hline & Dribbling & $\begin{array}{l}\text { This exercise should be taught along with passing and } \\
\text { shooting skills as well as the correct right movements of } \\
\text { legs. }\end{array}$ \\
\hline
\end{tabular}

\subsubsection{Introduction and management}

\subsubsection{Warm-up}

- Jogging for 10/20 meters. The exercise is to be repeated several times,

- Flexibility: Holding a stick by the hands in a vertical position in front of thighs,

- Lifting arms overhead, then backward towards one's back,

- Synchronisation and good timing: Throwing the ball against wall and receiving it,

- Balancing: balancing oneself on the ball using one leg, while moving the free leg, in different directions. Cube, brick or medical ball can be used instead of the ball,

- Strength and Durability off Muscles: clasping hands and holding partner.

\subsubsection{Exercises required}

- Gymnastics: vaulting horse

\subsubsection{Team games}

- Basketball,

- Passes: chest-pass, one-handed pass and intercepted pass, 
- Dribbling: this exercise should be taught along with passing and shooting skills as well as the correct right movements of legs.

\subsubsection{Concluding activities}

- The learner circles his/her arms forward and to the sides. Then backward and downward.

\subsection{The Second Lesson}

Table 6: Third Year Secondary - Boys: 2nd Lesson

\begin{tabular}{|c|c|c|c|c|}
\hline \multicolumn{5}{|c|}{ Introduction and Management } \\
\hline \multicolumn{3}{|c|}{ Warm-up } & \multicolumn{2}{|r|}{ Description } \\
\hline \multicolumn{3}{|c|}{$\begin{array}{l}\text { Agility, Lightness or elasticity of Body sprinting (10 } \\
\text { meters) }\end{array}$} & \multicolumn{2}{|c|}{$\begin{array}{l}\text { It is to be carried out as contests between } \\
\text { groups }\end{array}$} \\
\hline \multicolumn{3}{|c|}{ Energy \& Power } & \multicolumn{2}{|c|}{ Wide jump from a stationary stance } \\
\hline \multicolumn{3}{|c|}{ Precision } & \multicolumn{2}{|c|}{ Boomerang } \\
\hline \multicolumn{3}{|c|}{ Durability \& Muscle strength } & \multicolumn{2}{|c|}{$\begin{array}{l}\text { Squatting while keeping the waist } \\
\text { stationary then marching forward }\end{array}$} \\
\hline \multicolumn{3}{|c|}{ Durability of the respiratory system } & \multicolumn{2}{|c|}{ Jogging round pitch for two minutes } \\
\hline \multicolumn{5}{|c|}{ Skills required } \\
\hline \multicolumn{2}{|c|}{ Athletics } & \multicolumn{3}{|c|}{ Games (basketball) } \\
\hline Skills & Description & Skills & & Description \\
\hline \multirow[t]{2}{*}{ Jogging } & \multirow[t]{2}{*}{$\begin{array}{l}\text { Organising a } 100 \text {-meter- } \\
\text { running competition. }\end{array}$} & \multicolumn{2}{|l|}{ Shots } & $\begin{array}{l}\text { Stationary and from a } \\
\text { running approach } \\
\text { towards the goal, one and } \\
\text { two-handed shot, lay-up }\end{array}$ \\
\hline & & \multicolumn{2}{|c|}{$\begin{array}{l}\text { Dribbling, passing, and } \\
\text { shooting techniques to be } \\
\text { taught in combination } \\
\text { through actual practising of } \\
\text { the game. }\end{array}$} & \\
\hline \multirow[t]{2}{*}{ Relay } & \multirow{2}{*}{$\begin{array}{l}\text { Organising a circular relay } \\
\text { race event. Four equal teams } \\
\text { compete. Distance between } \\
\text { runners in the formation is } \\
\text { about } 10 \text { meters. }\end{array}$} & \multicolumn{2}{|c|}{ Defending duties } & $\begin{array}{l}\text { Correct manoeuvring and } \\
\text { movements }\end{array}$ \\
\hline & & \multicolumn{2}{|c|}{$\begin{array}{l}\text { Demonstration and actual } \\
\text { practice }\end{array}$} & \\
\hline \multicolumn{5}{|c|}{ Concluding activities } \\
\hline \multicolumn{5}{|c|}{$\begin{array}{l}\text { - } \quad \text { Arms, then stretching them upward. } \\
\text { - } \quad \text { Bending arms Bending arms then stretching them toward the sides. } \\
\text { - } \quad \text { Bending then stretching them forward and downward. }\end{array}$} \\
\hline
\end{tabular}

\subsubsection{Introduction and management}

\subsubsection{Warm-up}

- Agility, Lightness or elasticity of body: sprinting (10 meters). It is to be carried out as contests between groups,

- Energy and Power: Wide jump from a stationary stance, 
- Precision: Boomerang,

- Durability and Muscle Strength: Squatting while keeping the waist stationary then marching forward,

- Durability of the respiratory system: jogging round pitch for two minutes.

\subsubsection{Skills required}

\subsubsection{Athletics}

- Jogging: organizing a 100-meter-running competition,

- Relay: organizing a circular relay race event. Four equal teams compete. Distance between runners in the formation is about 10 meters.

\subsubsection{Games}

- Basketball

\subsubsection{Skills required to be practiced}

- Shots: stationary and from a running approach towards the goal, one and twohanded shot, lay-up,

- Dribbling, passing, and shooting techniques to be taught in combination through actual practicing of the game,

- Defending duties: correct manoeuvrings and movements,

- Demonstration and actual practice.

\subsubsection{Concluding activities}

- Arms, then stretching them upward,

- Bending arms bending arms then stretching them toward the sides,

- Bending then stretching them forward and downward.

\subsection{The Third Lesson}

Table 7: Third Year Secondary - Boys: 3rd Lesson

\begin{tabular}{|l|l|}
\hline Introduction and Management & Description \\
\hline Warm-up & Jogging on the spot for ten seconds. \\
\hline Speed & Standing with legs stretched out. \\
\hline Flexibility & $\begin{array}{l}\text { Jumping with the legs open from a standing stance, } \\
\text { lifting arms to the sides in a downward direction. Raising } \\
\text { arms to the sides again in an upward direction (Star } \\
\text { Jump). }\end{array}$ \\
\hline Synchronisation or good timing & walking while trying to keep balance on the beam. \\
\hline Balancing & $\begin{array}{l}\text { Jumping three times from a stationary position, then } \\
\text { bending knees on the fourth count. }\end{array}$ \\
\hline Strength and Muscle durability & \multicolumn{2}{|l|}{} \\
\hline Skills required & Games (Handball) \\
\hline Gymnastics & Skill Description \\
\hline Skill Description &
\end{tabular}




\begin{tabular}{|l|l|}
\hline \hline $\begin{array}{l}\text { Practising the Cartwheel with a quarter } \\
\text { turn, followed by backward roll. }\end{array}$ & $\begin{array}{l}\text { The following attacking and defending techniques: } \\
\text { - Four attacking players versus four defending players } \\
\text { - Five attacking players versus four defending players }\end{array}$ \\
\hline Concluding activities \\
\hline $\begin{array}{l}\text { From a standing stance with feet comfortably open, the learner circles his/her arms forward in a } \\
\text { downward direction, then in an upward direction. Bending trunk forward while thrusting arms } \\
\text { between legs. }\end{array}$ \\
\hline
\end{tabular}

\subsubsection{Introduction and management}

\subsubsection{Warm-up}

- Speed: Jogging on the spot for ten seconds,

- Flexibility: Standing with legs stretched out,

- Synchronisation or good timing: Jumping with the legs open from a standing stance, lifting arms to the sides in a downward direction. Raising arms to the sides again in an upward direction (Star Jump),

- Balancing: walking while trying to keep balance on the beam,

- Strength and Muscle durability: Jumping three times from a stationary position, then bending knees on the fourth count.

\subsubsection{Skills targeted}

- Gymnastics,

- Practicing the Cartwheel with a quarter turn, followed by backward roll.

\subsubsection{Games}

- Handball

The following attacking and defending techniques:

- Four attacking players versus four defending players,

- Five attacking players versus four defending players.

\subsubsection{Concluding activities}

From a standing stance with feet comfortably open, the learner circles his/her arms forward in a downward direction, then in an upward direction. Bending trunk forward while thrusting arms between legs.

\subsection{The Fourth Lesson}

Table 8: Third Year Secondary - Boys: 4th Lesson

\begin{tabular}{|l|l|}
\hline Introduction and Management & Description \\
\hline Warm-up & Running \\
\hline Agility, lightness or elasticity of body & Vertical leap \\
\hline Power and capability & Shooting at the goal \\
\hline Precision & $\begin{array}{l}\text { Standing while waist is stationary, then bending } \\
\text { knees halfway (squat). }\end{array}$ \\
\hline Strength and muscle durability &
\end{tabular}


REDEVISED EDITION OF PHYSICAL SKILLS COMPETENCIES OF PHYSICAL EDUCATION CURRICULUM CONTENT OF THE THIRD YEAR SECONDARY SCHOOL IN OMAN

\begin{tabular}{|c|c|}
\hline \multicolumn{2}{|l|}{ Skills required } \\
\hline Athletics & Games (Handball) \\
\hline Skill Description & Skill Description \\
\hline 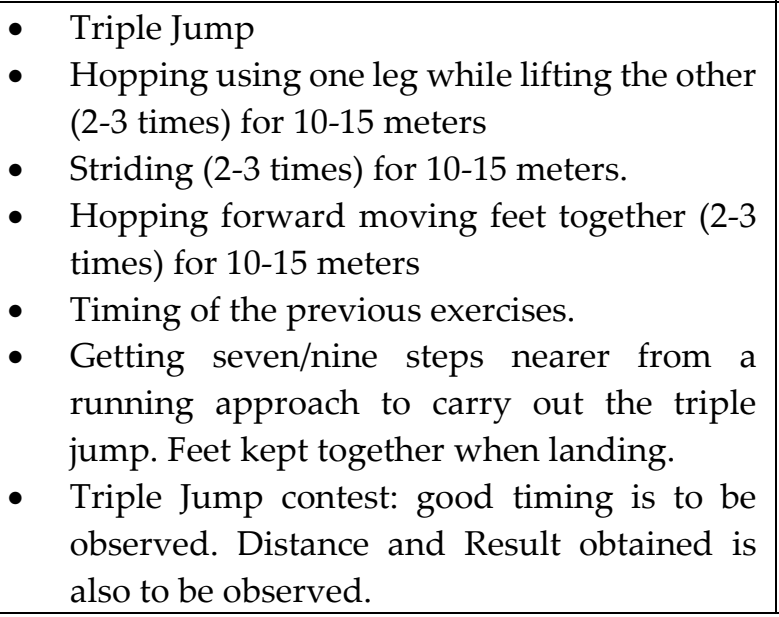 & $\begin{array}{l}\text { Defensive and attacking duties: } \\
\text { - Co-ordinating attacking and defensive duties. } \\
\text { Carrying out } 4 / 2 \text { formation for attacking duties. } \\
\text { Carrying out defensive duties along one line } \\
(6 / 0) \\
\text { - Co-ordinating assaulting duties - passing and } \\
\text { receiving the ball - exchanging positions while } \\
\text { charging at the goal }(5 / 1) \text { formation - co- } \\
\text { ordinating defensive duties - defensive } \\
\text { coverage }(1 / 5) \text { formation. }\end{array}$ \\
\hline \multicolumn{2}{|l|}{ Concluding activities } \\
\hline ns forward in a downward airectic & n \\
\hline
\end{tabular}

\subsubsection{Introduction and management}

\subsubsection{Warms-up}

- Agility, lightness or elasticity of body: Running,

- Power and capability: Vertical Leap,

- Precision: Shooting at the goal,

- Strength and muscle durability: standing while waist is stationary, then bending knees halfway (Squat).

\subsubsection{Athletics}

- Triple jump

- Hopping using one leg while lifting the other (2-3 times) for 10-15 meters,

- Striding (2-3 times) for 10-15 meters,

- Hopping forward moving feet together (2-3 times) for 10-15 meters,

- Timing of the previous exercises,

- Getting seven/nine steps nearer from a running approach to carry out the triple jump. Feet kept together when landing,

- Triple Jump contest: good timing is to be observed. Distance and Result obtained is also to be observed.

\subsubsection{Games}

- Handball

- Defensive and attacking duties,

- Co-ordinating attacking and defensive duties. Carrying out 4/2 formation for attacking duties. Carrying out defensive duties along one line (6/0), 
- Co-ordinating assaulting duties - passing and receiving the ball - exchanging positions while charging at the goal (5/1) formation - co-ordinating defensive duties -defensive coverage (1/5) formation.

\subsubsection{Concluding activities}

Swinging arms forward in a downward direction, then in an upward direction while raising and lowering the heels (vertical swinging)

\subsection{The Fifth Lesson}

Table 9: Third Year Secondary - Boys: 5th Lesson

\begin{tabular}{|l|l|}
\hline Introduction and Management & Description \\
\hline Warm-up & $\begin{array}{l}\text { 10-20-Metre relay race- participants are to be } \\
\text { divided into teams of equal numbers. They line up } \\
\text { in a relay formation }\end{array}$ \\
\hline Flexibility & $\begin{array}{l}\text { Standing up back-to-back holding a ball, then } \\
\text { passing the ball overhead, through the legs, and to } \\
\text { the sides. }\end{array}$ \\
\hline Balance & $\begin{array}{l}\text { Standing stance with the hands clasped and } \\
\text { bending the knees. A team mate helps with carrying } \\
\text { out balancing }\end{array}$ \\
\hline Synchronisation and Good timing & Dribble using one hand. \\
\hline Strength and Muscle durability & $\begin{array}{l}\text { From a standing position - while waist remaining } \\
\text { stationary - knees bent halfway (squat exercises). }\end{array}$ \\
\hline Skills required & Games (Volleyball) \\
\hline Gymnastics & Skill Description \\
\hline Skill Description & $\bullet \quad$ Underhand serve \\
\hline $\begin{array}{l}\text { Vaulting Horse } \\
\text { Vaulting while legs are open on approach, } \\
\text { while resting hands on the apparatus during } \\
\text { vaulting }\end{array}$ & \begin{tabular}{l} 
The spike or overhead-strike with open hand \\
\hline Concluding activities
\end{tabular} \\
\hline $\begin{array}{l}\text { Standing with the legs open and the arms raised up, bending waist backward while attempting to } \\
\text { touch heels one at a time. Repeating the exercise three times, pressing each time on the heels one at a } \\
\text { time. }\end{array}$ \\
\hline
\end{tabular}

\subsubsection{Introduction and management}

\subsubsection{Warm-up}

- Speed: 10-20-meter relay race- participants are to be divided into teams of equal numbers. They line up in a relay formation,

- Flexibility: standing up back-to-back holding a ball, then passing the ball overhead, through the legs, and to the sides,

- Balance: Standing stance with the hands clasped and bending the knees. A team mate helps with carrying out balancing,

- Synchronisation and Good timing: dribble using one hand, 
- Strength and Muscle durability: From a standing position - while waist remaining stationary - knees bent halfway (squat exercises).

\subsubsection{Gymnastics}

- Vaulting horse,

- Vaulting while legs are open on approach, while resting hands on the apparatus during vaulting.

\subsubsection{Team Games}

- Volleyball,

- Underhand serve,

- The spike or overhead-strike with open hand,

- The block.

\subsubsection{Concluding activities}

Standing with the legs open and the arms raised up, bending waist backward while attempting to touch heels one at a time. Repeating the exercise three times, pressing each time on the heels one at a time.

\subsection{The Lesson Six}

Table 10: Third Year Secondary - Boys: 6th Lesson

\begin{tabular}{|c|c|c|c|}
\hline \multicolumn{4}{|l|}{ Introduction and Management } \\
\hline \multicolumn{2}{|l|}{ Warm-up } & \multicolumn{2}{|l|}{ Description } \\
\hline \multicolumn{2}{|l|}{ Agility, lightness, and elasticity of body } & \multicolumn{2}{|c|}{ Jogging round a five-meter-square } \\
\hline \multicolumn{2}{|l|}{ Power } & \multicolumn{2}{|c|}{$\begin{array}{l}\text { Throwing a medical ball or an alternative } \\
\text { object to the furthest distance possible. }\end{array}$} \\
\hline \multicolumn{2}{|l|}{ Precision } & \multicolumn{2}{|c|}{ Kicking the ball towards the goal } \\
\hline \multicolumn{2}{|l|}{ Strength and Muscle durability } & \multicolumn{2}{|c|}{$\begin{array}{l}\text { Sitting down with hands and legs } \\
\text { touching the ground, then lifting the legs } \\
\text { up. }\end{array}$} \\
\hline \multicolumn{2}{|l|}{ Durability of Respiratory system } & \multicolumn{2}{|c|}{$\begin{array}{l}\text { Climbing (stepping) up and down on a } \\
\text { bench for a minute. }\end{array}$} \\
\hline \multicolumn{4}{|l|}{ Skills required } \\
\hline \multirow{2}{*}{$\begin{array}{l}\text { Gymnastics } \\
\text { (The Shot Ball) }\end{array}$} & \multicolumn{3}{|c|}{ Games } \\
\hline & Volleyball & & Soccer \\
\hline Skill Description & \multicolumn{3}{|c|}{ Skill Description } \\
\hline \multirow{2}{*}{$\begin{array}{l}\text { Throwing the shot ball from a } \\
\text { stationary position several times - } \\
\text { correcting mistakes in the process. } \\
\text { Repeating the exercise stressing on } \\
\text { the throwing circle, throwing stance, } \\
\text { lifting, holding, and throwing the shot } \\
\text { ball. }\end{array}$} & \multicolumn{2}{|l|}{ The Block } & $\begin{array}{l}\text { Moving the ball with short } \\
\text { running kicks. }\end{array}$ \\
\hline & \multicolumn{2}{|c|}{$\begin{array}{l}\text { Volleyball Contest and } \\
\text { simplified Volleyball rules } \\
\text { (touching the ball and the } \\
\text { blocking) }\end{array}$} & $\begin{array}{l}\text { Practising the different } \\
\text { types of kicks }\end{array}$ \\
\hline
\end{tabular}




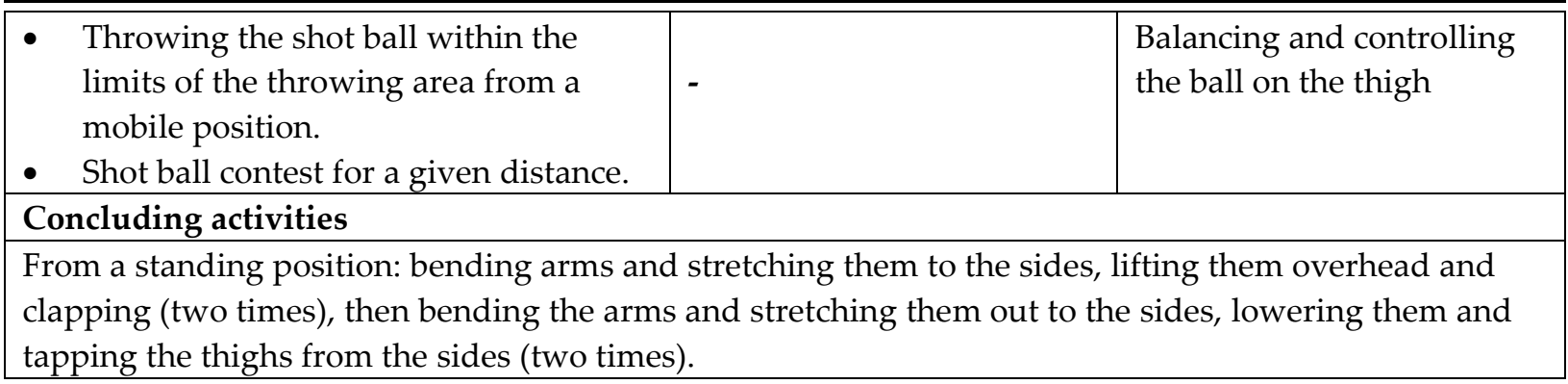

\subsubsection{Introduction and management}

\subsubsection{Warm-up}

- Agility, Lightness, and elasticity of body: jogging round a five-meter-square,

- Power: Throwing a medical ball or an alternative object to the furthest distance possible,

- Precision: Kicking the ball towards the goal,

- Strength and Muscle Durability: Sitting down with hands and legs touching the ground, then lifting the legs up,

- Durability off Respiratory system: Climbing (stepping) up and down on a bench for a minute.

\subsubsection{Gymnastics}

- The Shot ball,

- Throwing the shot ball from a stationary position several times - correcting mistakes in the process,

- Repeating the exercise stressing on the throwing circle, throwing stance, lifting, holding, and throwing the shot ball,

- Throwing the shot ball within the limits of the throwing area from a mobile position,

- Shot ball contest for a given distance.

\subsubsection{Team games}

- Volleyball,

- The Block,

- Volleyball contest and simplified Volleyball rules (touching the ball and the blocking),

- Soccer,

- Moving the ball with short running kicks,

- Practicing the different types of kicks,

- Balancing and controlling the ball on the thigh. 


\subsubsection{Concluding activities}

From a standing position: bending arms and stretching them to the sides, lifting them overhead and clapping (two times), then bending the arms and stretching them out to the sides, lowering them and tapping the thighs from the sides (two times).

\subsection{The Seventh Lesson}

Table 11: Third Year Secondary - Boys: 7th Lesson

\begin{tabular}{|l|l|}
\hline Introduction and Management & Description \\
\hline Warm-up & $\begin{array}{l}\text { Relay race for } 30 \text { meters. Students are to stand at the starting line. } \\
\text { Standing a step behind, a chaser whose role is to chase the player in } \\
\text { front of him when the race starts. }\end{array}$ \\
\hline Elasticity of Body and agility & $\begin{array}{l}\text { From a standing position, swinging legs forward in an upward } \\
\text { direction, then swinging them backward in an upward direction, } \\
\text { one leg at a time. }\end{array}$ \\
\hline $\begin{array}{l}\text { Synchronisation and Good } \\
\text { Timing }\end{array}$ & \begin{tabular}{l} 
Dribbling a football. \\
\hline Balancing
\end{tabular} \\
\hline Strength and Muscle strength & $\begin{array}{l}\text { Stepping forward form crouching position while waist stationary } \\
\text { (Lunge Exercise). }\end{array}$ \\
\hline Skills required & $\begin{array}{l}\text { Games } \\
\text { (Soccer) }\end{array}$ \\
\hline $\begin{array}{l}\text { Gymnastics } \\
\text { (Selection of exercises) }\end{array}$ & Skill Description \\
\hline Skill Description & Eluding to shoot \\
\hline Forward and backward rolls & Simplistic attacking techniques \\
\hline Diving forward roll & An exercise to beat the offside trap \\
\hline $\begin{array}{l}\text { Turning right to the long sitting } \\
\text { position }\end{array}$ & - \\
\hline Raising legs & \\
\hline
\end{tabular}

\subsubsection{Introduction and management}

\subsubsection{Warm-up}

- Speed: relay race for 30 meters. Students are to stand at the starting line. Standing a step behind, a chaser whose role is to chase the player in front of him when the race starts,

- Elasticity of Body and agility: from a standing position, swinging legs forward in an upward direction, then swinging them backward in an upward direction, one leg at a time,

- Synchronisation and Good Timing: Dribbling a football,

- Balancing: balancing oneself,

- Strength and Muscle strength: Stepping forward form crouching position while waist stationary (Lunge Exercise). 


\subsubsection{Gymnastics}

A selection of exercises including:

- Forward and backward rolls,

- Diving forward roll,

- Turning right to the long sitting position,

- Raising legs.

\subsubsection{Games}

- Soccer,

- Eluding to shoot,

- Simplistic attacking techniques,

- An exercise to beat the offside trap.

\section{B. Third Year Secondary - Girls}

\subsection{The First Lesson}

Table 12: Third Year Secondary - Girls: 1st Lesson

\begin{tabular}{|c|c|c|}
\hline \multicolumn{3}{|l|}{ Introduction and Management } \\
\hline \multicolumn{2}{|l|}{ Warm-up } & Description \\
\hline \multicolumn{2}{|l|}{ Speed } & Jogging (10-20 Meters). Repeating the exercise. \\
\hline \multicolumn{2}{|l|}{ Good timing and synchronisation } & Hitting ball against wall and receiving it. \\
\hline \multicolumn{2}{|l|}{ Strength and Muscle Durability } & Clasping hands and grabbing partner. \\
\hline \multicolumn{3}{|c|}{ Rhythmic Exercises } \\
\hline \multicolumn{3}{|c|}{$\begin{array}{l}\text { Free bodybuilding exercises of muscles. The exercises include neck, head, legs, arms, back, waist, trunk } \\
\text { and belly. }\end{array}$} \\
\hline \multicolumn{3}{|c|}{ Skills required } \\
\hline Gymnastics & \multicolumn{2}{|c|}{$\begin{array}{l}\text { Games } \\
\text { (Basketball) }\end{array}$} \\
\hline \multirow[t]{3}{*}{ The Cartwheel } & Skill: & Description \\
\hline & Passes & $\begin{array}{l}\text { Chest pass- one-handed pass- intercepted pass- } \\
\text { quick pass with precision }\end{array}$ \\
\hline & Dribble & $\begin{array}{l}\text { Connecting dribbling to passing, shooting and } \\
\text { correct movement of legs }\end{array}$ \\
\hline \multicolumn{3}{|l|}{ Concluding activities } \\
\hline \multicolumn{3}{|c|}{ Swinging arms to the sides - swinging arms downward } \\
\hline
\end{tabular}

\subsubsection{Introduction and management}

\subsubsection{Warm-up}

- Speed: Jogging (10-20 Meters). Repeating the exercise,

- Good timing and synchronisation: Hitting ball against wall and receiving it,

- Strength and Muscle Durability: clasping hands and grabbing partner. 


\subsubsection{Rhythmic exercises}

Free bodybuilding muscle exercises. The exercises include neck, head, legs, arms, back, waist, trunk and belly.

\subsubsection{Gymnastics}

The Cartwheel

\subsubsection{Games}

\section{Basketball}

- Passes: Chest pass- one-handed pass- intercepted pass- quick pass with precision,

- Dribble- connecting dribbling to passing, shooting and correct movement of legs.

\subsubsection{Concluding activities}

Swinging arms to the sides - swinging arms downward

\subsection{The Second Lesson}

Table 13: Third Year Secondary - Girls: 2nd Lesson

\begin{tabular}{|c|c|c|c|}
\hline \multicolumn{4}{|l|}{ Introduction and Management } \\
\hline \multicolumn{2}{|l|}{ Warm-up } & \multicolumn{2}{|l|}{ Description } \\
\hline Agility, Lightness and elasticity of body & & \multicolumn{2}{|c|}{ 10-Meter-run. A running contest is to be arranged. } \\
\hline \multicolumn{2}{|l|}{ Precision } & \multicolumn{2}{|c|}{ The Boomerang. } \\
\hline \multicolumn{2}{|l|}{ Strength and Muscle durability } & \multicolumn{2}{|c|}{$\begin{array}{l}\text { Stepping forward from a crouching stance while } \\
\text { waist stationary. }\end{array}$} \\
\hline \multicolumn{4}{|l|}{ Rhythmic Exercises } \\
\hline Balancing & \multicolumn{2}{|c|}{ Pacing backward } & Hold-release exercises. \\
\hline \multicolumn{4}{|l|}{ Skills required } \\
\hline \multicolumn{2}{|l|}{ Gymnastics } & \multicolumn{2}{|l|}{$\begin{array}{l}\text { Games } \\
\text { (Basketball) }\end{array}$} \\
\hline \multicolumn{2}{|l|}{ Skill Description } & $\begin{array}{l}\text { Skill } \\
\text { (Shots) }\end{array}$ & Description \\
\hline \multicolumn{2}{|c|}{ Running - Jogging- relay. } & \multirow{2}{*}{$\begin{array}{l}\text { Two-handed } \\
\text { shot }\end{array}$} & \multirow{2}{*}{$\begin{array}{l}\text { One-handed shot from a stationary } \\
\text { position and while moving }\end{array}$} \\
\hline \multicolumn{2}{|c|}{$\begin{array}{l}\text { Run and leap, exchanging knees - run and jump } \\
\text { - running while increasing speed } 20-30 \text { meters. }\end{array}$} & & \\
\hline \multicolumn{2}{|c|}{ Jogging for 30/50 - 70-100 Meters. } & \multirow{3}{*}{$\begin{array}{l}\text { Lay-up and } \\
\text { jump shot }\end{array}$} & \multirow{3}{*}{$\begin{array}{l}\text { Connecting these skills during } \\
\text { actual practice of the game }\end{array}$} \\
\hline \multicolumn{2}{|l|}{ Circular relay 4/50Meter. } & & \\
\hline \multicolumn{2}{|l|}{ A running contest for short distances. } & & \\
\hline \multicolumn{4}{|l|}{ Concluding activities } \\
\hline \multicolumn{4}{|c|}{$\begin{array}{l}\text { Bending arms and expanding them to the sides. Then bending them and spreading them upwards. } \\
\text { Bending arms and spreading them forward. Bending arms then spreading them downwards. }\end{array}$} \\
\hline
\end{tabular}

\subsubsection{Introduction and management}

\subsubsection{Warm-up}

- Agility, Lightness and elasticity of Body: 10-meter-run. A running contest is to be arranged. 
- Precision: the Boomerang.

- Strength and Muscle Durability: Stepping forward from a crouching stance while waist stationary.

\subsubsection{Rhythmic exercises}

Balancing - pacing backward - hold-release exercises.

\subsubsection{Gymnastics}

- Running - Jogging- relay.

- Run and leap, exchanging knees - run and jump - running while increasing speed 20-30 meters.

- Jogging for 30/50 - 70-100 Meters.

- Circular relay 4/50Meter.

- A running contest for short distances.

\subsubsection{Games}

\section{Basketball}

- Shots: Two-handed shot - one-handed shot from a stationary position and while moving

- Lay-up and jump shot - connecting these skills during actual practice of the game

\subsubsection{Concluding activities}

Bending arms and expanding them to the sides. Then bending them and spreading them upwards. Bending arms and spreading them forward. Bending arms then spreading them downwards.

\subsection{The Third Lesson}

Table 14: Third Year Secondary - Girls: 3rd Lesson

\begin{tabular}{|l|l|}
\hline Introduction and Management & Description \\
\hline Warm-up & Jogging on the spot. \\
\hline Speed & $\begin{array}{l}\text { Leaping from a standing poise with legs open. Stretching } \\
\text { arms at the level of shoulders. Then moving them } \\
\text { downward and upward. }\end{array}$ \\
\hline Synchronisation and Timing & $\begin{array}{l}\text { Leaping on the spot (three times), bending knees at the } \\
\text { fourth count. }\end{array}$ \\
\hline Strength and Muscle durability & \multicolumn{2}{|l|}{} \\
\hline Rhythmic Exercises & $\begin{array}{l}\text { Games } \\
\text { Mobile exercises (walking/running/leaping/jumping/sliding). }\end{array}$ \\
\hline Skills required & Skill \\
\hline Gymnastics &
\end{tabular}




\begin{tabular}{|l|l|}
\hline \hline Forward and backward roll & Defending \\
\hline Handstand & Correct advance \\
\hline The cartwheel & Demonstration and actual practice of the game \\
\hline Concluding activities \\
\hline Swinging arms in an upward movement - bending waist forward while pressing arms between legs. \\
\hline
\end{tabular}

\subsubsection{Introduction and management}

\subsubsection{Warm-up}

- Speed: Jogging on the spot.

- Synchronisation and Timing: Leaping from a standing poise with legs open. Stretching arms at the level of shoulders. Then moving them downward and upward.

- Strength and Muscle durability: leaping on the spot (three times), bending knees at the fourth count.

\subsubsection{Rhythmic exercises}

Exercises involving no equipment.

Mobile exercises (walking/running/leaping/jumping/sliding).

\subsubsection{Athletics}

Gymnastics

- Forward and backward roll - handstand - the cartwheel

\subsubsection{Games}

Basketball

- Defending

- Correct advance

- Demonstration and actual practice of the game

\subsubsection{Concluding activities}

Swinging arms in an upward movement - bending waist forward while pressing arms between legs.

\subsection{The Fourth Lesson}

Table 15: Third Year Secondary - Girls: 4th Lesson

\begin{tabular}{|l|l|}
\hline Introduction and Management & Description \\
\hline Warm-up & Running \\
\hline Elasticity of body and Agility & Shooting at a target (cube etc.) using hands. \\
\hline Precision & $\begin{array}{l}\text { Bending knees halfway from a standing poise } \\
\text { while waist stationary (squat exercises). }\end{array}$ \\
\hline Strength and Muscle durability & \\
\hline Rhythmic Exercises &
\end{tabular}




\begin{tabular}{|c|c|c|}
\hline \multicolumn{3}{|c|}{$\begin{array}{l}\text { Stationary exercises requiring no equipment: } \\
\text { turning - involving body in circular movements }\end{array}$} \\
\hline \multicolumn{3}{|c|}{ Skills required } \\
\hline \multicolumn{2}{|c|}{ Athletics } & $\begin{array}{l}\text { Games } \\
\text { (Volleyball) }\end{array}$ \\
\hline Skill & Description & Skill \\
\hline \multirow[b]{3}{*}{$\begin{array}{l}\text { Long } \\
\text { jump }\end{array}$} & $\begin{array}{l}\text { Long jump for a distance while } \\
\text { attempting to reach a given distance }\end{array}$ & Underhand serve \\
\hline & A long jumping contest & The spike \\
\hline & $\begin{array}{l}\text { High Jump (reviewing high jump } \\
\text { exercises - high jump contest }\end{array}$ & The block \\
\hline \multicolumn{3}{|c|}{ Concluding activities } \\
\hline \multicolumn{3}{|c|}{ Swinging arms forward then upward and downward while lifting heels (Vertical swing) } \\
\hline
\end{tabular}

\subsubsection{Introduction and management}

\subsubsection{Warm-up}

- Elasticity of body and Agility: running,

- Precision: shooting at a target (cube etc.) using hands,

- Strength and Muscle durability: Bending knees halfway from a standing poise while waist stationary (squat exercises).

\subsubsection{Rhythmic exercise}

Stationary exercises requiring no equipment: turning - involving body in circular movements.

\subsubsection{Athletics}

\section{Long jump:}

- Long jump for a distance while attempting to reach a given distance,

- A long jumping contest,

- High Jump (reviewing high jump exercises - high jump contest.

\subsubsection{Games}

Volleyball

- Underhand serve,

- The spike,

- The block.

\subsubsection{Concluding activities}

Swinging arms forward then upward and downward while lifting heels (Vertical swing) 


\subsection{The Fifth Lesson}

Table 16: Third Year Secondary - Girls: 5th Lesson

\begin{tabular}{|l|l|}
\hline Introduction and Management & Description \\
\hline Warm-up & $\begin{array}{l}\text { Standing back to back holding a ball. Then passing the } \\
\text { ball overhead, pass between legs and to the sides. }\end{array}$ \\
\hline Elasticity of Body and lightness & $\begin{array}{l}\text { Clasping hands with a partner. Then bending knees. } \\
\text { Balance is to be controlled by a partner. }\end{array}$ \\
\hline Balance & One-handed Dribble \\
\hline Synchronisation and timing & \\
\hline Rhythmic Exercises & \multicolumn{2}{|l|}{} \\
\hline A selection of free exercises (64 counts) & $\begin{array}{l}\text { Games } \\
\text { (Volleyball) }\end{array}$ \\
\hline Skills required & Skill \\
\hline Gymnastics & Defensive duties \\
\cline { 2 - 2 } & Actual contest and simplistic rules of the game \\
\cline { 2 - 2 } Skill Description & $\begin{array}{l}\text { Test of skills (handling the ball - the block - touching } \\
\text { the net and lines - the spike) }\end{array}$ \\
\hline $\begin{array}{l}\text { Vaulting Horse } \\
\text { Vaulting while opening legs on the } \\
\text { approach, resting palms on the apparatus. }\end{array}$ \\
\hline Concluding activities
\end{tabular}

\subsubsection{Introduction and management}

\subsubsection{Warm-up}

- Elasticity of Body and lightness: Standing back to back holding a ball. Then passing the ball overhead, pass between legs and to the sides,

- Balance: Clasping hands with a partner. Then bending knees. Balance is to be controlled by a partner,

- Synchronisation and timing: One-handed Dribble.

\subsubsection{Rhythmic exercises}

A selection of free exercises (64 counts)

\subsubsection{Athletics}

Gymnastics

Vaulting Horse

- Vaulting while opening legs on the approach, resting palms on the apparatus.

\subsubsection{Games}

\section{Volleyball}

- Defensive duties,

- Actual contest and simplistic rules of the game,

- Test of skills (handling the ball - the block - touching the net and lines - the spike). 


\subsubsection{Concluding activities}

From a standing position while legs open and arms lifted up, the student bends and tries to touch heels one at a time (three times).

\subsection{The Sixth Lesson}

Table 17: Third Year Secondary - Girls: 6th Lesson

\begin{tabular}{|c|c|c|c|}
\hline \multicolumn{4}{|c|}{ Introduction and Management } \\
\hline \multicolumn{2}{|c|}{ Warm-up } & \multicolumn{2}{|l|}{ Description } \\
\hline \multicolumn{2}{|c|}{ Elasticity of body and Agility } & \multicolumn{2}{|c|}{$\begin{array}{l}\text { Running round a five-meter-square. This } \\
\text { exercise is to be carried out as a running contest } \\
\text { between teams }\end{array}$} \\
\hline \multicolumn{2}{|l|}{ Capability } & \multicolumn{2}{|c|}{$\begin{array}{l}\text { Throwing a medical ball or an alternative object } \\
\text { to furthest distance possible. }\end{array}$} \\
\hline \multicolumn{2}{|c|}{ Durability of the respiratory system } & \multicolumn{2}{|c|}{ Climbing up and down using a bench. } \\
\hline \multicolumn{4}{|c|}{$\begin{array}{l}\text { Rhythmic exercises } \\
\text { (Exercises involving the use of ropes and streamers) }\end{array}$} \\
\hline Leaping & \multicolumn{2}{|l|}{ Forward \& backward skipping } & $\begin{array}{l}\text { Turning \& swinging rope of } \\
\text { streamer }\end{array}$ \\
\hline \multicolumn{4}{|c|}{ Skills required } \\
\hline \multicolumn{2}{|c|}{ Athletics } & \multicolumn{2}{|l|}{$\begin{array}{l}\text { Games } \\
\text { (Volleyball) }\end{array}$} \\
\hline Skill & Description & Skill & Description \\
\hline \multirow{3}{*}{ The disks } & $\begin{array}{l}\text { Techniques of throwing } \\
\text { (throwing in the air - throwing } \\
\text { forward - throwing using one } \\
\text { hand - throwing using both } \\
\text { hands. }\end{array}$ & \multirow{3}{*}{$\begin{array}{l}\text { Defensive \& } \\
\text { assaulting } \\
\text { duties. }\end{array}$} & $\begin{array}{l}\text { Four attackers versus four } \\
\text { defenders }\end{array}$ \\
\hline & $\begin{array}{l}\text { Throwing the disks while } \\
\text { moving within the limits of the } \\
\text { throwing circle. }\end{array}$ & & $\begin{array}{l}\text { Five defenders versus four } \\
\text { attackers }\end{array}$ \\
\hline & $\begin{array}{l}\text { A contest of throwing the disks } \\
\text { while moving for a given } \\
\text { distance. }\end{array}$ & & $\begin{array}{l}\text { Five attackers versus four } \\
\text { defenders }\end{array}$ \\
\hline \multicolumn{4}{|c|}{ Concluding activities } \\
\hline \multicolumn{4}{|c|}{$\begin{array}{l}\text { From a standing position, bending arms and stretching them to the sides. Then lifting them overhead } \\
\text { and clapping two times. Stretching arms to the sides, lowering them patting two times on the thighs. }\end{array}$} \\
\hline
\end{tabular}

\subsubsection{Introduction and management}

\subsubsection{Warm-up}

- Elasticity of body and Agility: running round a five-meter-square. This exercise is to be carried out as a running contest between teams

- Capability: throwing a medical ball or an alternative object to furthest distance possible.

- Durability of the respiratory system: climbing up and down using a bench. 


\subsubsection{Rhythmic exercises}

Exercises involving the use of ropes and streamers,

Leaping - forward and backward skipping - turning and swinging rope of streamer,

\subsubsection{Athletics}

The disks

- Techniques of throwing (throwing in the air - throwing forward - throwing using one hand - throwing using both hands,

- Throwing the disks while moving within the limits of the throwing circle,

- A contest of throwing the disks while moving for a given distance.

\subsubsection{Games}

\section{Handball}

Defensive and assaulting duties. Practicing the following duties:

- Four attackers versus four defenders,

- Five defenders versus four attackers,

- Five attackers versus four defenders.

\subsubsection{Concluding activities}

From a standing position, bending arms and stretching them to the sides. Then lifting them overhead and clapping two times. Stretching arms to the sides, lowering them patting two times on the thighs.

\subsection{The Seventh Lesson}

Table 18: Third Year Secondary - Girls: 6th Lesson

\begin{tabular}{|l|l|}
\hline \multicolumn{2}{|l|}{ Third Year Secondary - Girls: $7^{\text {th }}$ LESSON } \\
\hline Introduction and Management & Description \\
\hline Warm-up & $\begin{array}{l}\text { Relay race for 30 meters. Students stand in equal rows. A chaser, standing } \\
\text { a step behind, is assigned to each front runner. The relay race starts when } \\
\text { a start sign is given. }\end{array}$ \\
\hline Speed & Balancing from a standing stance. \\
\hline Balance & Stepping forward from a crouching stance (Lunge Exercises). \\
\hline $\begin{array}{l}\text { Strength and Muscle } \\
\text { Durability }\end{array}$ & $\begin{array}{l}\text { Rhythmic Exercises } \\
\text { (Exercises involving the use of banner) }\end{array}$ \\
\hline $\begin{array}{l}\text { Swinging arms while } \\
\text { holding the banner }\end{array}$ & Throwing and receiving the banner \\
\hline Skills required & $\begin{array}{l}\text { Games } \\
\text { (Handball) }\end{array}$ \\
\hline Gymnastics & Skill \\
\hline Skill & Carrying out attacking and defending duties \\
\cline { 2 - 2 } Vaulting horse & Executing the attacking technique (4/2) as a team \\
\hline
\end{tabular}




\begin{tabular}{|l|l|}
\hline \hline Flank vaulting & Executing the defensive technique (6/0) as a team \\
\hline $\begin{array}{l}\text { Laying down a program } \\
\text { for gymnastics }\end{array}$ & $\begin{array}{l}\text { Attacking the goal as a team with a 5/1 attacking formation, exchanging } \\
\text { position, passing and receiving the ball. }\end{array}$ \\
\hline- & Defending and covering as a team with a 1/5 defensive formation. \\
\hline Concluding activities \\
\hline $\begin{array}{l}\text { From a standing position, bending arms while pressing elbows backward two times. Stretching arms } \\
\text { to the sides three times, then lowering them four times. }\end{array}$ \\
\hline
\end{tabular}

\subsubsection{Introduction and management}

\section{Warm-up}

- Speed: Relay race for 30 meters. Students stand in equal rows. A chaser, standing a step behind, is assigned to each front runner. The relay race starts when a start sign is given.

- Balance: Balancing from a standing stance.

- Strength and Muscle Durability: Stepping forward from a crouching stance (Lunge Exercises).

\subsubsection{Rhythmic exercises}

- Exercises involving the use of banner,

- Swinging arms while holding the banner,

- Throwing and receiving the banner.

\subsubsection{Athletics}

\section{Gymnastics}

- Vaulting horse,

- Flank vaulting,

- Laying down a program for gymnastics.

\subsubsection{Games: Handball}

- Carrying out attacking and defending duties,

- Executing the attacking technique (4/2) as a team,

- Executing the defensive technique (6/0) as a team,

- Attacking the goal as a team with a 5/1 attacking formation, exchanging position, passing and receiving the ball,

- Defending and covering as a team with a $1 / 5$ defensive formation.

\subsubsection{Concluding activities}

From a standing position, bending arms while pressing elbows backward two times. Stretching arms to the sides three times, then lowering them four times. 


\section{Conclusion}

In summary, the present study found that physical skills on third year secondary school was effective in the curriculum of physical education Al Sinani \& Al Rawahi, (2012). But the division of physical skills competencies can be effective as if it reshapes in the physical education plan Al Sinani (2019), so the study suggests a 10-lesson plan with reconstruction the physical skills competencies during the third year Trudea \& Shephard (2008), which may help to improve apply the physical skills competencies. The study revealed a weakness in the availability of knowledge competencies according to the Physical skills. The study recommends the strengthening and training of the cognitive skills and competencies Al Sinani (2019).

\section{Conflict of Interest Statement}

No potential conflict of interest was reported by the authors.

\section{About the Author}

Dr. Yousra AL-Sinani is an associated professor at the Colleges of Education at Sultan Qaboos University Sultanate of Oman former deputy dean of the Education Faculty of Sultan Qaboos University, Muscat, Oman, with special responsibility for training and community service. She was the first Omani woman to gain a Ph.D. in the subject of physical education through her studies in England. In July 2009, Yousra was awarded the Kluka Love Award for her presentation at the IAPESGW World Congress in South Africa. and Sultan Qaboos University Award for International Awards 2012. Yousra has made an outstanding contribution to the management of the IAPESGW 2008 International Seminar hosted by her university, which led to the 'Accept and Respect' Declaration. The principles of the declaration have been underpinned much advocacy work in the field around the world. Her research contributed to the depth of understanding in terms of Islamic rules and Arabic cultures. As a result of her own written work in the field of Women sport of Oman, Oman acknowledged her for as one of the supporting committee members in women sport in the region. orcid.org/0000-0002-0858-849X

\section{References}

Alleger, A. N. (1993). Physical Education Evaluation Teacher, Elementary School, Professional Preparation, Teaching Program, Portuguese, Sangallo.

Almond, L. (1989). The Place of Physical Education in Schools. London: Kogan Page L. Al Sinani, Y. (2019). Reflection on the Objective of Physical Education Department from Lecturers point of view Physical Education Department at Sultan Qaboos University. Association of Arab Educators. 2, (16), 147-160. 
Al Sinani, Y. (2017). The Establishment and Development of the Initial Physical Education Teachers' Training Program for Women in Oman. Sport in the Middle East: Power, Politics, Ideology and Religion; Vol. 29, No. 15; 85 - 110.

AL Sinani, Y. \& Al Rawahi, N. Y. (2012). Evaluating the Physical Education Omani National Curriculum from PE Teachers Perspective. Scientific Journal \& Educational Science, 16, 241-223.

Al Sinani, Y. (2014). A Necessity in Today's Time: Physical Education in Oman. International Journal of Learning Management Systems, 2 (1), 21-32

Armstrong, N. and Sparkes, A. (1991) Issues in Physical Education. London: Cassell.

Brown, C. and Cassidy, R. (1963) Theory in Physical Education a Guide to Program Change. London: Henry Kimpon.

Edward, S.L. (2010). Challenges facing teaching and learning of physical education in primary schools Bwiri/Nanguba zone, Samia sub-county, Kenya. (Unpublished master thesis), Kenyatta University, Kenya.

Evans, J. (1986) Physical Education, Sport and Schooling: Studies in The Sociology of Physical Education. U.K: Falmer press.

Caple, S. (1996). Learning to Teach Physical Education in The Secondary School: A Companion to School Experience. London: Routledge.

Hardy, C. A, and Mawer, M. (1999). Learning and Teaching in Physical Education. Britain: Falmer press.

Lindeburg, F. A. (1978) Teaching Physical Education in The Secondary School. Canada: John Wiley and sons.

Ministry of Education (1991). Manual Report 90. Muscat: Ministry of Education.

Ministry of Education (1993). Regulations of the General Education. No 21 article 5. Muscat: Ministry of Education.

Ministry of Education (2002a). Basic Education in the Sultanate of Oman - the Theoretical Framework. Muscat: Ministry of Education.

Ministry of Education (2002b). Basic Education in the Sultanate of Oman, A Guide to the First Cycle, Grades $1-4$. Muscat: Ministry of Education.

Ministry of Education (2005). Educational Development in Oman. Muscat: Ministry of Education.

Massengale, J. D. (1987). Trends Toward the Future in Physical Education. Champaign: Human Kinetics.

Mosston, M. and Ashworth, S. (1986). Teaching Physical Education. (3d Ed). Coulombs: Merrill.

Phillips, D. Hornak, J (1999). Measurement and Evaluation in Teaching Program, Players journal of sports Medicine and physical fitness (Torino) 33 (1) Mar. pp.69-69, refs

Taba, H. (1962). Curriculum Development: Theory and Practice. New York: Harcourt, Bracce \& Jovanovich.

Trudeau, F., and Shephard, R. J. (2008). Physical Education and School Physical Activity and School Sports and Academic Performance. International Journal of Behavioural Nutrition and Physical Activity; 5(10): 1-12. 
Underwood, G. L. (1983). The Physical Education Curriculum in the Secondary School: Planning and Implementation. Sussex: The Falmer Press.

Creative Commons licensing terms

Authors will retain the copyright of their published articles agreeing that a Creative Commons Attribution 4.0 International License (CC BY 4.0) terms will be applied to their work. Under the terms of this license, no permission is required from the author(s) or publisher for members of the community to copy, distribute, transmit or adapt the article content, providing a proper, prominent and unambiguous attribution to the authors in a manner that makes clear that the materials are being reused under permission of a Creative Commons License. Views, opinions and conclusions expressed in this research article are views, opinions and conclusions of the author(s). Open Access Publishing Group and European Journal of Physical Education and Sport Science shall not be responsible or answerable for any loss, damage or liability caused in relation to/arising out of conflict of interests, copyright violations and inappropriate or inaccurate use of any kind content related or integrated on the research work. All the published works are meeting the Open Access Publishing requirements and can be freely accessed, shared, modified, distributed and used in educational, commercial and non-commercial purposes under a Creative Commons attribution 4.0 International License (CC BY 4.0). 